Western North American Naturalist 70(2), (C) 2010, pp. 233-237

\title{
EVALUATION OF BROOD DETECTION TECHNIQUES: RECOMMENDATIONS FOR ESTIMATING GREATER SAGE-GROUSE PRODUCTIVITY
}

\author{
David K. Dahlgren ${ }^{1,2}$, Terry A. Messmer ${ }^{1}$, Eric T. Thacker ${ }^{1}$, and Michael R. Guttery ${ }^{1}$
}

\begin{abstract}
Obtaining timely and accurate assessment of sage-grouse (Centrocercus spp.) chick survival and recruitment is an important component of species management and conservation. We compared the effectiveness of walking, spotlight, and pointing-dog surveys to detect radio-marked and unmarked chicks within broods of radio-marked hens in Utah. Walking surveys detected $72 \%$ of marked chicks, while spotlight and pointing-dog surveys detected $100 \%$ and $96 \%$, respectively. We found no difference between spotlight and pointing-dog counts in number of marked and unmarked chicks detected $(P=0.57)$. Spotlight counts were slightly more time efficient than pointing-dog surveys. However, spotlight surveys were nocturnal searches and perceived to be more technically arduous than diurnal pointing-dog surveys. Pointing-dog surveys may offer greater utility in terms of area searched per unit effort and an increased ability to detect unmarked hens and broods.
\end{abstract}

Key words: brood counts, Centrocercus urophasianus, Greater Sage-Grouse, pointing dogs, spotlighting, walking surveys, Utah.

Recent declines in Greater Sage-Grouse (Centrocercus urophasianus, hereafter sagegrouse) populations have been attributed to low productivity and poor recruitment caused by declining habitat quantity and quality (Connelly and Braun 1997, Connelly et al. 2004). Concomitantly, obtaining reliable and costeffective estimates of productivity and recruitment has been identified as an important sage-grouse conservation strategy (Connelly et al. 2004, Crawford et al. 2004).

Multiple studies have reported uncertainty in locating all sage-grouse chicks around a radio-marked brood hen during walking flush counts and also have noted that this technique may underestimate juvenile survival (Schroeder 1997, Aldridge and Brigham 2001, Aldridge 2005). Burkepile et al. (2002) and Gregg et al. (2007) devised methods for radio-marking sagegrouse chicks, and these methods likely yielded more-reliable estimates of chick survival than traditional walking flush counts. However, radio-marking chicks is expensive and laborintensive, and not all research projects have sufficient funding to use the technique. Moreover, most managers interested in monitoring production do not have the resources required to monitor radio-marked hens or broods, especially at large-population or statewide scales. Clearly, from both research and management perspectives, better methods are needed for assessing productivity within sage-grouse populations.

The use of nocturnal brood surveys with spotlights may provide improved chick detection (Walker et al. 2006) over walking flush counts. Using dogs to locate individual chicks within a brood may also improve detection rates (Zwickel 1980). In North America, pointing dogs have been used specifically for sage-grouse research (Autenrieth 1981, Connelly et al. 2000b, 2003, Dahlgren et al. 2006). Connelly et al. (2003) recommended using pointing dogs for sage-grouse brood surveys. Nevertheless, in spite of all the North American and European grouse research studies that have used pointing dogs, we could not find any publications evaluating the effectiveness of pointing dogs for detecting grouse. The objectives of this study were (1) to determine if walking, spotlight, and pointing-dog surveys differed in their ability to detect chicks within radio-marked broods and (2) to evaluate the relative efficiency of walking, spotlight, and pointing-dog surveys in detecting chicks.

${ }_{1}^{1}$ Jack H. Berryman Institute, Department of Wildland Resources, Utah State University, 5230 Old Main Hill, Logan, UT 84322-5230.

2E-mail: dkdbio@gmail.com 


\section{Study AREA}

Parker Mountain is in Garfield, Sevier, Piute, and Wayne counties, Utah, USA, and encompasses approximately 107,000 ha. Elevation ranges from 2134 to $3018 \mathrm{~m}$, and precipitation averages from about 17 to $50 \mathrm{~cm}$, based on elevation. The area is grazed regularly by livestock-both sheep and cattle. The sagebrush (Artemisia spp.) habitat on Parker Mountain is one of the largest contiguous tracts in Utah. Parker Mountain continues to be one of the few remaining areas in Utah exhibiting relatively high densities of Greater Sage-Grouse (Beck et al. 2003). Most of Parker Mountain is dominated by black sagebrush (Artemisia nova). Lower draws and higher-elevation areas on the western edge of the mountain are dominated by mountain big sagebrush (Artemisia tridentata vaseyana). Herbaceous cover is generally lower on Parker Mountain than in sagebrush-dominated landscapes at more-northern latitudes. Multiple vegetation treatments have occurred recently to improve herbaceous cover in higher-elevation habitats used for late broodrearing.

\section{Methods}

\section{Survey Methods}

We used 3 methods (walking, spotlight, and pointing-dog surveys) to detect 5-8-week-old broods of radio-marked hens. During July and August of 2006 and 2007, we conducted surveys within a time period of 24-36 hours to reduce possible bias due to brood-mixing (a common occurrence for this population; Dahlgren 2009) or chick mortality within a given brood. Prior to our counts, we assigned a random order in which the 3 methods would be used for a given brood. These broods had been previously captured at approximately one day old and marked with 1.5-g radios following Burkepile et al. (2002). However, only a portion of chicks were radio-marked in each brood, leaving unmarked chicks as well.

We used the hen's signal to find the brood's general location, and search efforts were centered on her position. We then used the different survey methods to flush/detect chicks (marked and unmarked) within the brood. We checked the signals of radio-marked chicks prior to sampling to make sure they were alive and in the brood's vicinity, but we did not get a specific location of each chick. We then checked the brood area after sampling to see if we had detected/flushed the marked chicks. If more than one hen flushed with chicks during the surveys, the number of chicks per brood was averaged by hen.

Spotlighting was conducted at night between 22:00 and 02:00 by 2 observers (a spotter/driver and a telemetry aide). Marked and unmarked chicks were detected using binoculars. For walking counts, one observer approached the brood during the day (usually morning or evening) and slowly walked in a spiral pattern (approximately 5-10-m spacing between spirals) around the brood hen's location for 20 minutes. This time period was used for both walking and pointing-dog count methods for consistency and comparison; however, spotlight counts were a single occurrence in time. Time to detection of chicks was considered as part of the relative efficiency of each method.

For pointing-dog flush counts, we kept the dogs' search pattern less than approximately $100 \mathrm{~m}$ from the radio-collared hen's flush location. We approached the radio-marked brood location from downwind initially to give the dog the best scenting conditions possible (Gutzwiller 1990). Our observer/handler minimized human influence on the dog's search pattern by remaining relatively stationary until the dog went on point. We used 3 dogs to conduct the surveys. All dogs used in this study had been trained on sage-grouse and specifically on the study site (Gutzwiller 1990). Additionally, all 3 dogs had at least 2 full years of experience (>30 days per year) searching for wild game birds, including sage-grouse. All dogs were trained to hold point until the observer flushed the bird.

\section{Data Analysis}

We used data from all detected/flushed chicks (both radio-marked and unmarked) and assumed that no brood-mixing and/or chick mortality occurred during the sampling period. The data were censored if brood-mixing or chick mortality was detected for radio-marked chicks. We used one-way ANOVA in a randomized block design, where broods were blocks, to test for count differences in flushcount methodology (significance determined by $P<0.05)$. We also calculated the percent of marked chicks detected by each method. 
TABLE 1. Walking, nocturnal spotlight, and pointing-dog flush count results for Greater Sage-Grouse (Centrocercus urophasianus) marked broods (a combination of radiomarked and unmarked chicks) on Parker Mountain, Utah, 2006-2007.

\begin{tabular}{lcc}
\hline Method $^{\mathrm{a}}$ & Mean chicks/brood & SE \\
\hline Walking & 2.80 & 0.64 \\
Spotlight & 5.30 & 0.75 \\
Pointing-dog & 4.56 & 0.66 \\
\hline
\end{tabular}

Each method was conducted on a single brood

\section{RESUlts}

We surveyed 21 radio-marked broods during $2006(n=14)$ and $2007(n=7$; combined total of 25 marked chicks for both years). Most broods had a radio-marked hen, but some only had a marked chick due to brood-mixing prior to our survey efforts. For the combined marked and unmarked chick data, the number of chicks detected differed by technique $(F=7.25, P=$ 0.001). Pairwise comparisons showed that walking flush counts detected on average approximately 2 fewer chicks per brood than spotlight $(t=3.68, P=0.002)$ and pointing-dog flush counts $(t=2.73, P=0.03$; Table 1$)$ and no difference between spotlight and pointing-dog flush counts $(t=-1.01, P=0.57)$. Probabilities of detection for marked chicks on walking, pointing-dog, and spotlight flush surveys were $0.72,0.96$, and 1.00 , respectively. All chicks were detected within the first $10 \mathrm{~min}$ utes of the pointing-dog survey period. This was not the case with walking flush counts. We did have 2 mortalities of marked chicks during our survey period, and one case of brood-mixing by a marked chick (data were censored).

\section{Discussion}

Our results have direct application to research objectives. Walking flush counts were the least-effective method for detecting chicks within broods. This finding suggests that previously reported survival estimates based on walking surveys underestimated sage-grouse chick survival. Spotlighting and pointing-dog flush counts were most effective at detecting chicks and exhibited similar detection rates. These 2 methods could improve brood counts and chick survival estimates for research on radio-marked brood hens without radiomarked chicks. Mortality and brood-mixing for radio-marked chicks was minimal during our sampling period. Spotlighting entailed the least amount of time per brood to conduct the survey, once a radio-marked brood was located; however, nocturnal surveys were logistically more difficult (i.e., causing disruption of daytime work schedules and presenting challenges of conducting telemetry work in the darkness of night) compared to daytime walking and pointing-dog flush counts. Pointing-dog surveys were also very efficient due to the dogs' superior ground coverage and scenting/detection abilities.

Trained and experienced dogs are a prerequisite for fieldwork using pointing dogs (Gutzwiller 1990, Connelly et al. 2003). Training reliable pointing dogs requires dedication and time, and we recommend that dogs have at least 2 years of experience on the species of interest. Many regions have local pointingdog clubs with various dog breeds and field test/trial groups (e.g., American Kennel Club Hunting Tests/Trials, North American Versatile Hunting Dog Association). Also, many regions have upland game conservation organizations that could provide volunteer handlers and dogs for this work (Dahlgren et al. 2006).

Our results also have application to routine management surveys. Currently, some states attempt population-level production estimates with sage-grouse brood surveys (Connelly et al. 2005). Pointing dogs may also be used to locate grouse broods at landscape levels (Parker 1985, Schieck and Hannon 1989, Klott and Lindzey 1990, Redpath 1991, Novoa et al. 1996, Redpath and Thirgood 1999, Storaas et al. 1999, Connelly et al. 2003, Dahlgren et al. 2006) without the need for radio-marked birds, though our research did not specifically address this possibility. Once a brood is located, our results confirm that using pointing dogs is an effective method for accurately determining brood size. Spotlighting may also have utility for routine surveys, since this technique did allow us, while conducting nocturnal spotlight counts of radio-marked broods, to locate other unmarked broods roosting on black sagebrush ridges. However, the feasibility of using nocturnal spotlight counts at relatively broad scales may be affected by site-specific amount and distribution of low-structure sagebrush roosting habitat (e.g., open areas like black sagebrush ridgetops in our study) on the landscape. More 
research is required to assess the effectiveness of the spotlighting technique at differing landscape levels.

Wing surveys have been used to assess general population production (Connelly et al. 2003); however, harvest levels needed to produce enough wing data $(n \geq 300$; suggested by Hagen and Loughin 2008) for many sagegrouse populations may exceed conservative harvest criteria suggested by Connelly et al. (2000a). Furthermore, many sage-grouse populations are no longer harvested, and wing-based production data are unavailable. Therefore, in many cases the old, but often overlooked broodcount technique of using pointing dogs, or possibly spotlight counts, may provide an effective, low-cost means of assigning sage-grouse production at various scales.

\section{ACKNOWLEDGMENTS}

We thank the Utah State University Extension, the Jack H. Berryman Institute, the Quinney Professorship for Wildlife Conflict Management, the Utah Division of Wildlife Resources, the USDA Forest Service Loa Ranger District, the Natural Resource Conservation Service, and the USDI Bureau of Land Management for funding this project. We thank the Parker Mountain Adaptive Resource Management working group. We thank Susan Durham for her statistical expertise and advice. We also thank M. Richins for his aid in data collection. Last but not least, we thank Parker, Buddy, and Ginger for their hard work.

\section{Literature Cited}

ALDRIDGE, C.L. 2005. Identifying habitats for persistence of Greater Sage-Grouse (Centrocercus urophasianus) in Alberta, Canada. Doctoral dissertation, University of Alberta, Edmonton, Canada.

Aldridge, C.L., And R.M. Brigham. 2001. Nesting and reproductive activities of Greater Sage-Grouse in a declining northern fringe population. Condor 103:537-543.

Autenrieth, R.E. 1981. Sage grouse management in Idaho. Wildlife Bulletin 9, Idaho Department of Fish and Game, Boise, ID.

Beck, J.L., D.L. Mitchell, and B.D. Maxfield. 2003. Changes in the distribution and status of sagegrouse in Utah. Western North American Naturalist 63:203-214.

Burkepile, N.A., J.W. Connelly, D.W. Stanley, and K.P. REESE. 2002. Attachment of radiotransmitters to one-day-old sage grouse chicks. Wildlife Society Bulletin 30:93-96.
Connelly, J.W., A.D. Apa, R.B. Smith, And K.P. Reese. 2000a. Effects of predation and hunting on adult sage-grouse Centrocercus urophasianus in Idaho. Wildlife Biology 6:227-232.

Connelly, J.W., AND C.E. BRaun. 1997. Long-term changes in sage grouse Centrocercus urophasianus populations in western North America. Wildlife Biology 3:229-234.

Connelly, J.W., J. Gammonley, and J.M. Peek. 2005. Harvest management. Pages 658-690 in C.E. Braun, editor, Techniques for wildlife investigation and management. The Wildlife Society, Bethesda, MD.

Connelly, J.W., S.T. Knick, M.A. Schroeder, And S.J. STIVER. 2004. Conservation assessment of Greater Sage-Grouse and sagebrush habitats. Unpublished Report, Western Association of Fish and Wildlife Agencies, Cheyenne, WY.

Connelly, J.W., K.P. ReEse, And M.A. Schroeder. 2003. Monitoring of Greater Sage-Grouse habitats and populations. Station Bulletin 80, College of Natural Resources, University of Idaho, Moscow, ID.

Connelly, J.W., M.A. Schroeder, A.R. SAnds, and C.E. Braun. 2000b. Guidelines to manage sage grouse populations and their habitats. Wildlife Society Bulletin 28:967-985.

Crawford, J.A., R.A. Olson, N.E. West, J.C. Mosley, M.A. Schroeder, T.D. Whitson, R.F. Miller, M.A. GREgG, AND C.S. Boyd. 2004. Ecology and management of sage-grouse and sage-grouse habitat. Journal of Range Management 57:2-19.

DahlgRen, D.K. 2009. Greater Sage-Grouse ecology, chick survival, and population dynamics, Parker Mountain, Utah. Doctoral dissertation, Utah State University, Logan, UT.

DahlgRen, D.K., R. Chi, And T.A. Messmer. 2006. Greater Sage-Grouse response to sagebrush management in Utah. Wildlife Society Bulletin 34:975-985.

Gregg, M.A., M.R. Dunbar, and J.A. Crawford. 2007. Use of implanted radiotransmitters to estimate survival of Greater Sage-Grouse chicks. Journal of Wildlife Management 71:646-651.

GutzWILLER, K.J. 1990. Minimizing dog-induced biases in game bird research. Wildlife Society Bulletin 18:351-356

Hagen, C.A., And T.M. Loughin. 2008. Productivity estimates from upland bird harvests: estimating variance and necessary sample sizes. Journal of Wildlife Management 72:1369-1375.

KLOTT, J.H., AND F.G. Lindzey. 1990. Brood habitats of sympatric sage grouse and Columbian Sharp-Tailed Grouse in Wyoming. Journal of Wildlife Management 54:84-88.

Novoa, C., M. Catusse, and L. Ellison. 1996. Capercaillie (Tetrao urogallus) summer population census: comparison of counts with pointing dogs and route census. Gibier Faune Sauvage 13:1-11.

PARKer, H. 1985. Compensatory reproduction through renesting in Willow Ptarmigan. Journal of Wildlife Management 49:599-604.

RedPath, S.M. 1991. The impact of hen harriers on red grouse breeding success. Journal of Applied Ecology 28:659-671.

Redpath, S.M., AND S.J. ThiRgood. 1999. Numerical and functional responses in generalist predators: hen harriers and peregrines on Scottish grouse moors. Journal of Animal Ecology 68:879-892. 
Schieck, J.O., And S.J. Hannon. 1989. Breeding site fidelity in Willow Ptarmigan: the influence of previous reproductive success and familiarity with partner and territory. Oecologia 81:465-472.

SCHROEDER, M.A. 1997. Unusually high reproductive effort by sage grouse in a fragmented habitat in north-central Washington. Condor 99:933-941.

Storaas, T., L. Kastdalen, and P. Wegge. 1999. Detection of forest grouse by mammalian predators: a possible explanation for high brood losses in fragmented landscapes. Wildlife Biology 5:187-192

Walker, B.L., K.E. Doherty, and D.E. Naugle. 2006. Spotlight counts: a new method for assessing chick survival in Greater Sage-Grouse. Proceedings of the 25th Meeting of the Western Agencies Sage and Columbian Sharp-tailed Grouse Technical Committee, Spearfish, SD.

ZwICKEL, F.C. 1980. Use of dogs in wildlife biology. Pages 531-536 in S.D. Schemnitz, editor, Wildlife management techniques manual. 4th edition. The Wildlife Society, Inc., Washington, DC. 686 pp.

Received 5 June 2009 Accepted 30 October 2009 